\title{
新潟県下越地方における横屋－堅屋複合町屋の分布及び外観類型 DISTRIBUTION AND DESIGN CHARACTER OF "YOKOYA-TATEYA MIX TO MACHIYA" IN KAETSU REGION, NIIGATA PREFECTURE
}

\author{
渡辺篤史*, 岡崎篤行** \\ Atsushi WATANABE and Atsuyuki OKAZAKI
}

\begin{abstract}
The pupose of this paper is to clarify the number and the percentage of remaining Yokoya-Tateya mixed Machiya in Kaetsu area, and to understand design character of this building. Major results are as fillows:1) No Yokoya-Tateya mixed Machiya exist in nothern and southern Kaetsu region. On the other hand, there are many Yokoya-Tateya mixed Machiya in Naka-kanbara district and western Kita-kanbara district. It may be inferred that Yokoya-Tateya mixed Machiya was formed from Tateya. One of the reasons is becouse no Yokoya-Tateya mixed Machiya can be found in towns which are consisted purely of Yokoya.2) Several types of facade design are extracted from 740 Yokoya-Tateya mixed Machiya.3) As seen in old paintings and photographs, most Machiya in Niigata were Tateya in the late Edo and early Meiji period. The townscape changed in the mid meiji period, and many Yokoya-tateya mixed Machiya emerged.
\end{abstract}

Keywords : Town scape,Machiya, Yokoya,Tateya ,Syumoku,Niigata Prefecture 町並夕, 町屋, 横屋, 竪屋, 撞木, 新潟県

\section{1. 研究の背景と目的}

全国各地で歴史的町並みを活かしたまちづくりが進められている が、その一つとして町屋を中心とした町場の町並みがあげられる。 町屋については、地域性が把握しにくいと言われ、農家と比べると 全国規模での体系的な研究が立ち遅れている ${ }^{1)}$ と言われおり、体 系的な把握が必要である。例えば町屋の町並みの特徽を表現する上 で「妻入・平入」は複数の既往研究 ${ }^{1 \sim 2)}$ で述べられているとおり、 重要な要素のひとつである。特に都市計画の観点では、伝建地区の 保存計画にも記載があるとおり、町並夕景観の整備を図る上で基本 的な項目になる。一般的に建造物の棟の向きを表す用語として妻入 及び平入注1) が用いられるが、妻入、平入という表現では町並みを 適切に言い表せない場合があり、本研究では佐渡市相川における町

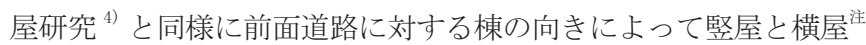

2）を用いることとする。

新潟県における町屋の棟向きに関する研究 ${ }^{5)}$ において、県内の 主要な町場の町屋を妻入と平入に大別したものがあるが、筆者らが 行ってきた歴史的建造物群に関する基礎的かつ広域的悉皆調查 ${ }^{6 \sim 9)}$ では、新潟市文化財旧小澤家住宅 ${ }^{10)}$ をはじめ、下越地方を中心に 前面道路側が 2 階建横屋とその後方に竪屋が複合した町屋（以下、 横屋-豎屋複合町屋）が多数見られ、町屋の一様式を成していた。 このようなものは全国的にあることが知られているが注3)、各集落 における調査はあるものの、その分布は局所的に変化する場合もあ
ることから、広域的に各集落を網羅的に調査寸ることが必要である。 また、新潟県内において、町屋の内部空間に着目した研究 ${ }^{13 \sim 14)}$ は あるが、外観形態に関するものはない。

そこで、本研究は新潟県下越地方における横屋-堅屋複合町屋の 分布と、各集落における典型的な外観類型を明らかにした上で、そ の中心都市、新潟町注 4) を対象に成立時期と普及要因を推測する。

\section{2. 研究の概要}

\section{2-1. 対象地概要}

下越地方は新潟県北部に位置し、概ね明治期における岩船郡、北・ 東・中・西蒲原郡の範囲である。下越地方には村上や新発田、村松、 峰山の城下町や瀬波や岩船、沼垂、新潟の湊町があり、これらや他 の地域を結ぶ街道が発達し、街道沿いには多くの在郷町がある。ま た、かつては船運が発達し、河川沿いにも在郷町がある。

\section{2-2. 横屋-堅屋複合町屋の概要（表 1)}

新潟県下越地方における横屋 - 竪屋複合町屋の広く知られたもの として岩船郡関川村下関の撞木造りが挙げられる。撞木造りは 18 世紀後半に上位階層が建造物の外形注5) が T 字型で屋根の棟が堅屋 と横屋が複合したものを先駆的に取り入れ、20世紀に入ってから 前棟二階建て・後棟一階建ての最も小型で簡潔な形式が生み出され たことによって普及したと言われている ${ }^{11)}$ 。また、屋根の形状は 乗越屋根のものが多く見受けられる。
* 新潟大学大学院自然科学研究科 大学院生 · 修士 (工学)

** 新潟大学工学部建設学科 教授·博士 (工学)
Grad. Stud., Grad. Sch. of Science and Technology, Niigata Univ., M.Eng. Prof., Dept. of Civil Eng. and Arch., Faculty of Eng., Niigata Univ., Dr.Eng. 
一方、旧新潟町を中心に見られる横屋-竪屋複合町屋は、多くが 外形が I 字型で、屋根形状は切妻が多い。後述するように、もとも と竪屋であったものが行政指導により前棟が横屋になったものと考 えられ、撞木造りとは成立要因が異なる。

そこで本研究では、屋根の棟が竪屋と横屋が複合したもののうち、 撞木造りの代表的な形態である外形が T 字型のものを除いたものを 研究対象の横屋-竪屋複合町屋とする。

なお、関東から南東北一円にかけてみられる店棟造りは店棟を住 居空間である座敷棟から明確に分離しており、構造的に独立し、通

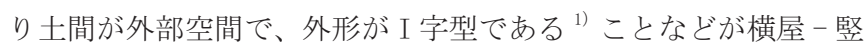
屋複合町屋と異なる。福井県三国町のかぐら建ては屋根形状が主と して片流れ - 切妻である点で異なる。

\section{2-3. 研究の方法}

調查対象とする集落は先行研究 ${ }^{6 \sim 9)}$ で調查を行った主要街道注 6 ) 及び河川沿いの町場のうち歴史的建造物注7) の主屋が 30 棟以上注8) 確認できた図 1 に示す 66 箇所とする。なお、調查対象集落は、い ずれも第二次世界大戦中大規模な空襲をうけておらず、集落全体が 壊滅的な被害に至っていない。

調査対象とする集落において、歴史的建造物主屋の棟向きを集計 することで、横屋-竪屋複合町屋の割合を算出し、横屋-豎屋複合町 屋の分布状況を把握する。ここで、横屋-堅屋複合町屋が 10 棟以上 の集落を対象に外形、階数、玄関面、奥行などの外観調査を行い、 その後類型化により地域的な特徵を明らかにする。なお、外観調査 は 2010 年 8 〜 12 月の期間で行った。

旧新潟町における成立と普及要因を推測するために、棟向きのわ かる絵図 ${ }^{(i 2)}$ 、明治期の建造物を描いた史料 ${ }^{23)}$ 、町並夕写真、町並 みや建築に関する法規制を調查する。

\section{3. 横屋-竪屋複合町屋の分布}

\section{3-1. 歴史的建造物主屋の棟向き}

調査対象集落のうち 56 集落において横屋-堅屋複合町屋が確認 された（図 1)。主屋の棟向きをみると、横屋が大半を占める村上・ 瀬波においては横屋-竪屋複合町屋を確認することができなかった。 また、横屋-竪屋複合町屋が確認されたすべての集落において竪屋 が確認できた。後述する通り、新潟町では横屋-堅屋複合町屋が堅 屋から派生した可能性が指摘され、横屋一竪屋複合町屋を堅屋に含 めると、主屋が 30 棟以上確認された 42 集落のうち 30 集落におい て竪屋が過半数を占めている。

\section{3-2. 横屋-㹂屋複合町屋の棟数と割合}

対象地域全体における横屋-竪屋複合町屋の棟数は 915 棟であっ た。集落別にみていくと、新潟町が 255 棟と最も多く、次いで新発 田が 124 棟、沼垂が 81 棟である。歷史的建造物の主屋に対寸る横 屋-豎屋複合町屋の割合は、亀田が $52 \%$ と最も高く、次いで下関が $50 \%$ である。旧岩船郡北部、旧西蒲原郡南部では横屋一豎屋複合町 屋はほぼ見られず、下越地方中央部に集中して分布している。特に 旧中蒲原郡から旧北蒲原郡にかけて多く分布している傾向がある。 なお、既往研究 6）と既往研究 24）において、街道と横屋-竪屋複 合町屋の分布の関係性を指摘されているが、下越地方においては線 的というよりは面的に広く分布していることがわかる。
表 1 対象地における横屋一堅屋複合町屋の例

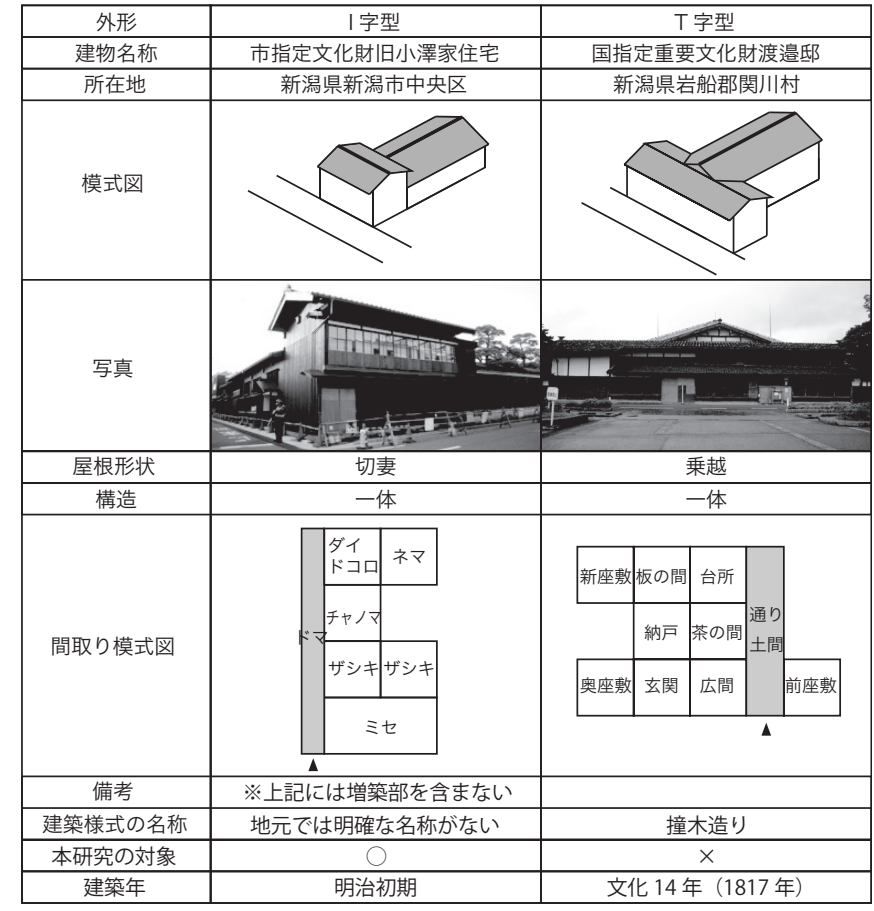

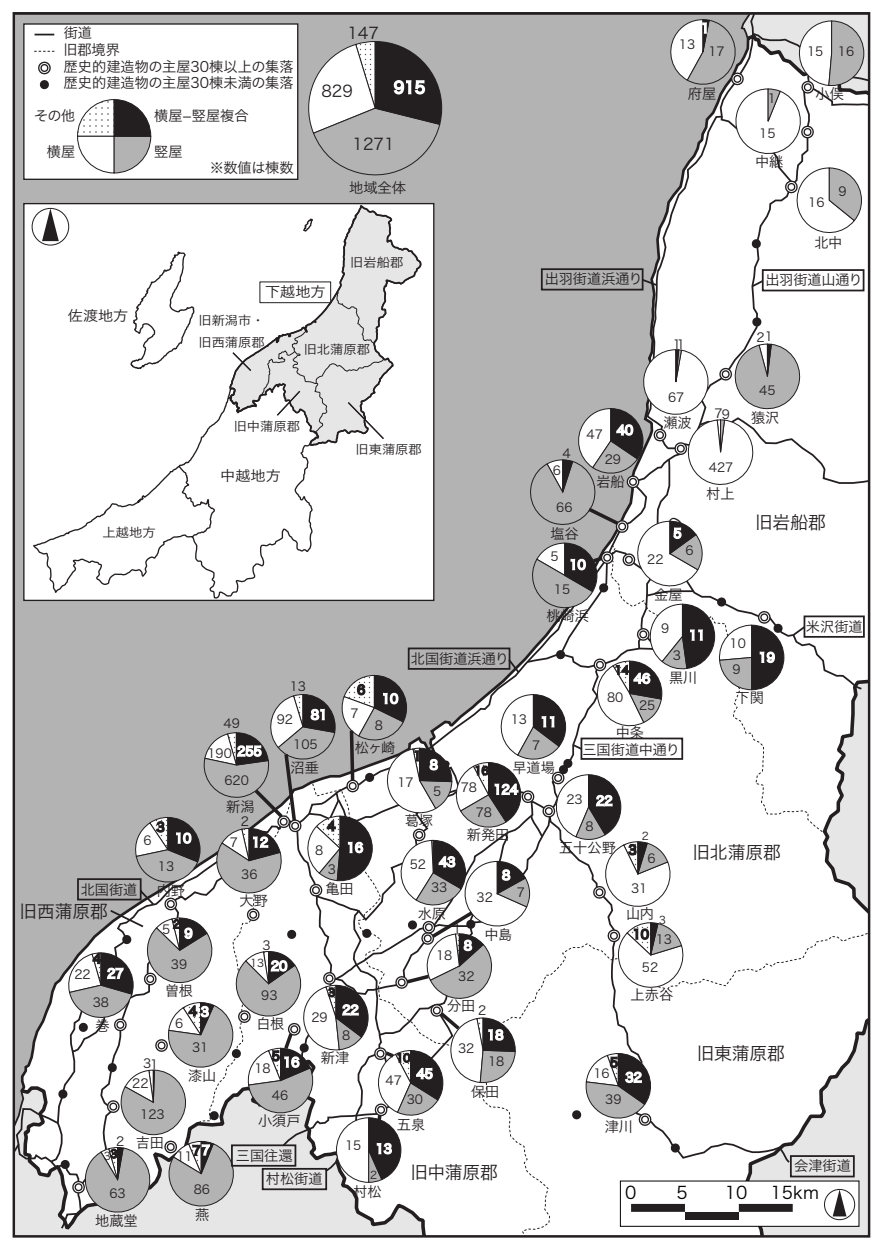

図 1 調査対象集落における歴史的建造物主屋の棟向き

\section{4. 横屋-朢屋複合町屋の類型}

4-1. 用途による分類（図 2)

横屋一豎屋複合町屋を戸建と長屋に分類すると、地域全体では戸 
建が 740 棟、長屋が 74 棟であり、長屋のほとんどが新潟に集中的 に分布している。そこで戸建について外観要素による類型化を行う。

\section{4-2. 戸建の外観要素による類型}

横屋-竪屋複合町屋のうち戸建 740 棟を図 3 のとおり「外形」「階 数注 ${ }^{10)}$ 」、「玄関面 ${ }^{12}$ 」1) 、「後棟奥行注 ${ }^{12)} 」 の$ 外観要素により 分類を行 った ${ }^{13)}$ 。結果多様なパターンに類型できたが、20 棟以上のものを 基本パターンとする。

基本タイプ 1 ～4 はそれぞれ外形が I 字型、玄関面が前棟平入 のものである。タイプ 1 は前棟後棟の階数が 2 階 -1 階で後棟の奥 行が長であり、基本タイプのなかで最も棟数が多い。松ケ崎・沼垂・ 新潟から村松にかけての一帯に分布する傾向がある。タイプ 2 は前 棟後棟の階数が 2 階 -1 階で後棟の奥行が短であり、海岸線沿いの 集落と新発田から村松にかけての一帯に分布する傾向がある。タイ プ 3 は前棟後棟の階数が 2 階 -2 階で後棟の奥行が長であり、新潟・ 沼垂から小須戸にかけての一帯と旧岩船郡南部に分布する傾向があ る。タイプ 4 は前棟後棟の階数が 2 階 -2 階で後棟の奥行が短であり、 43 棟のうち新潟 27 棟と過半数を占めている。基本タイプ $5 、 6$ は 外形が L 字型、玄関面が前棟平入、後棟長のものである。タイプ 5 は前棟後棟の階数が 2 階 -1 階で、五十公野において特に高い割合

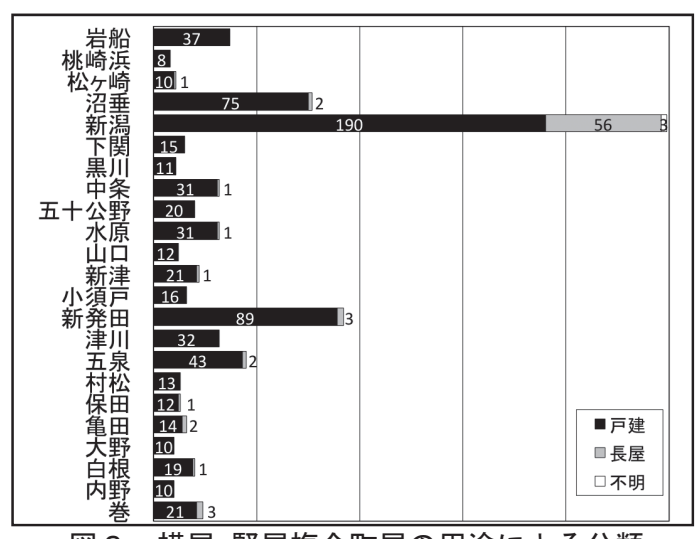

図 2 横屋-竪屋複合町屋の用途による分類

表 2 横屋-竪屋複合町屋（戸建）の外観要素による基本タイプ

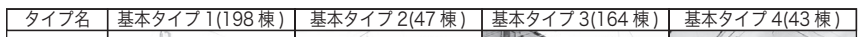

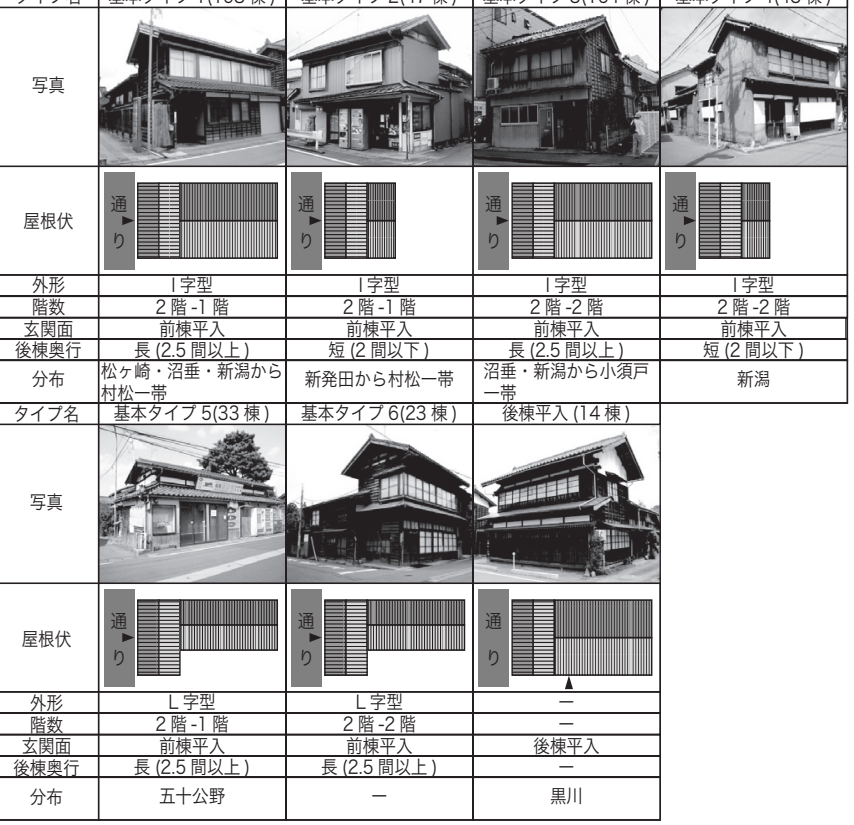

を占めている。タイプ 6 は前棟後棟の階数が 2 階 -2 階で 14 集落 で確認できたが高い割合を占めている集落はない。

また、特殊なものとして、立関面が後棟平入のものが黒川、岩船、 桃崎浜、五十公野、沼垂、新潟で確認できた。黒川において特に高 い割合を占めている。黒川において間取りを確認したところ、通り 土間をもたず、前棟はザシキのみで構成されていた。

\section{5. 新潟町における横屋-豎屋複合町屋の成立過程}

\section{5-1. 史料における横屋}

新潟町における町屋研究 ${ }^{9)}$ から現代において間口が狭く奥行き が長い縦長横屋は 1 棟も確認されていないことから、史料で単に

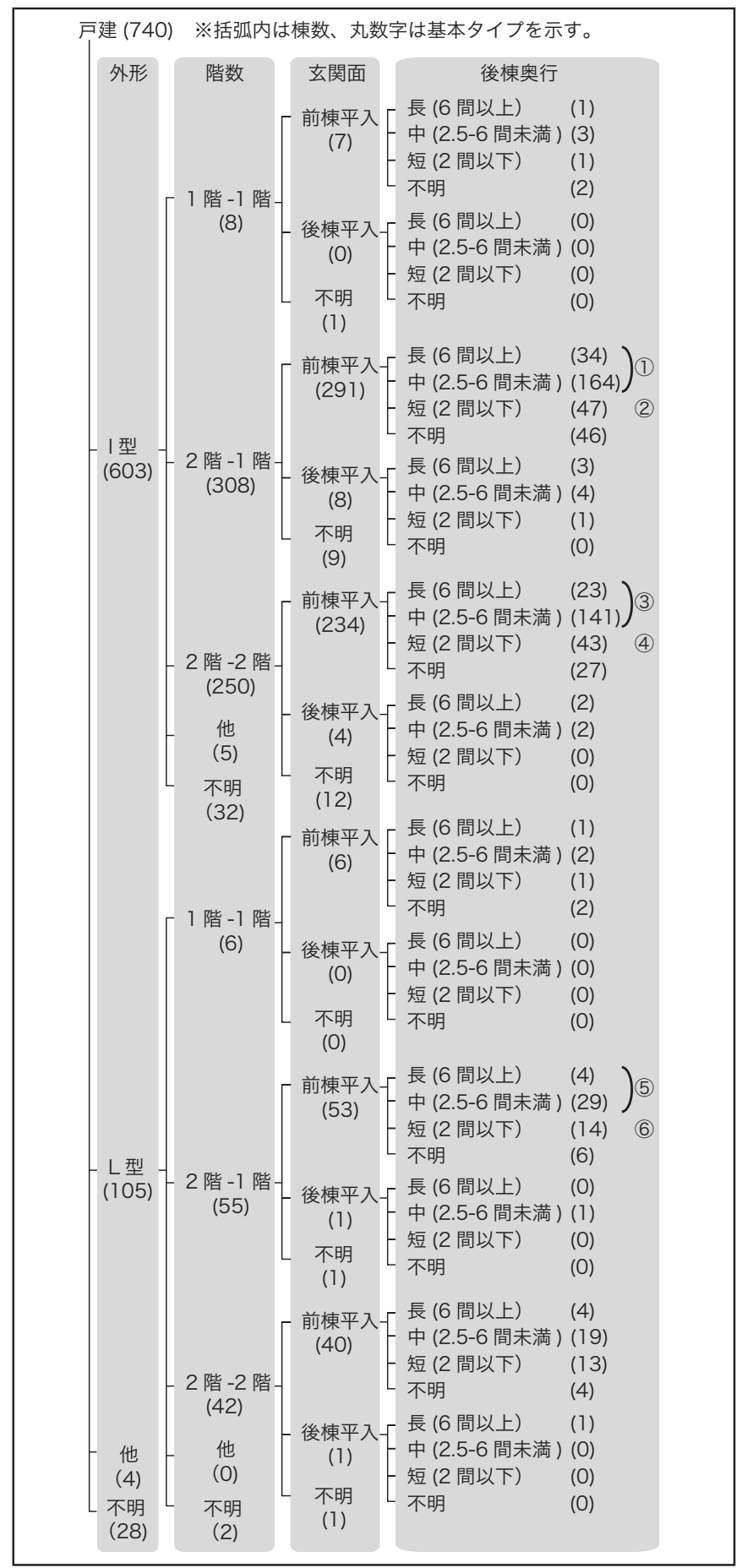

図 3 横屋-竪屋複合町屋（戸建）の外観要素による類型化 
横屋として描かれていても横屋-竪屋複合町屋である可能性がある。 よって、史料における横屋を前棟横屋と表現することにする。

\section{5-2. 絵図にみる江戸期・明治初期の棟向き}

江戸期から明治初期の旧新潟町の町並みを描いた絵図を可能な限 り収集した ${ }^{\text {注 }}{ }^{14)}$ 。表 3 は収集した絵図を年代が古い順に示す。

1831 年「北国一覧写」は、作者が旧新潟町を訪れて描いたもの で本町通では竪屋が複数確認でき、前棟横屋は 3 棟でそのうち 1 棟 に後棟が確認できた（図 5)。1849 年「新潟真景」は、新潟町全域 で竪屋が複数描かれ、前棟横屋は 2 棟で後棟は確認できない (図 6)。 1865 年「新潟真景」は、作者が新潟町を訪れて描いたもので横七 番町付近で竪屋が複数、前棟横屋が 6 棟で、うち 2 棟に後棟が確認 できた (図 7)。1869 年「新斥税関之圖」は新潟町全域で堅屋が複数、 前棟横屋は 10 棟で、うち 5 棟に後棟が確認できた（図 8)。

以上から、新潟町は江戸時代後期には竪屋の町並みであるが、遅 くとも北国一覧写が描かれた 1831 年には横屋-竪屋複合町屋が既 に存在していたと考えられる。

\section{5-3． 銅版画にみる明治 20 年代の棟向き}

明治前期の新潟町の様子を、建物 1 軒毎に示寸史料を見つけるこ とはできなかったが、1889 年「北越商工便覧」 ${ }^{23)}$ から明治期の商 家の棟向きがある程度分かる。北越商工便覧の町屋である商家 92 棟の棟向きをみると、前棟横屋 66 棟、横屋-堅屋複合町屋 13 棟、 堅屋 9 棟であり、前棟横屋がの約 7 割を占める（図 9)。次に北越 商工便覧とほぼ同時期に作製された、1896 年「新潟市商業家明細 全図」 ${ }^{25)}$ から立地場所の特定を行うと約 6 割 $(70 / 92)$ が立地場所 が判明した(図 10)。角地では横屋-豎屋複合町屋である場合が多い。

また、北越商工便覧とほぼ同時期の 1899 年に新潟市に滞在した 小説家の尾崎紅葉は紀行文で「町で一番繁華な町は古町通、次が本 町通で、家が立ち並んでいる。家屋は低く、桁端を通りに向けた妻 入りである。」と述べている ${ }^{26)}$ 。初田 ${ }^{27)}$ は明治前期の東京銀座の 商店・事業所を示寸銅版画「東京名家繁昌図録 初篇」について「経 済的に比較的ゆとりのある、あるいは発展に対して意欲的である商 店、事業所が銅版画に掲載されている」と述べている。このことか ら、北越商工便覧においても一部の有力な商家が掲載され、実際の 町並みは尾崎が見たように堅屋の町並みであったと考えられる。

\section{5-4． 町並み古写真にみる棟向きの変化}

明治初期から昭和初期にかけて古町通及び本町通の町並み写真 ${ }^{28}$ ３0）を収集した結果が表 4 である。このうち比較的多くの写真が収 集できた古町 5 番町では、少なくとも大正中期に前棟横屋が見ら れ、同様に古町 6 番町では少なくとも明治中期に前棟横屋が見られ た。これは、1880 年 (明治 13 年) の大火が一つの要因と考えられ る。古町 8 番町では明治中期の時点で既に前棟横屋があったことが わかる。また、本町 14 番町では昭和初期まで竪屋の町並みであるが、 これはこの地区が 1880 年に新設された遊郭であり、他の町丁とは 異なり竪屋の町並みが維持されたと考えられる。

\section{5-5． 景観政策による棟向きの変化}

新潟町において景観に配慮した定めが出されたのは 1872 年に新 潟へ赴任した楠本正隆が新築をする者に対して 1873 年「秝島榛島 江新規家建之定」を定め、そのなかで「庇八三尺通リ、腕木留入二 限リ候事」と庇の幅の統一を行ったことが最初である。「右之通家 建出来難キモノ八住居不相成候事」と条文の通りに家が建てられな

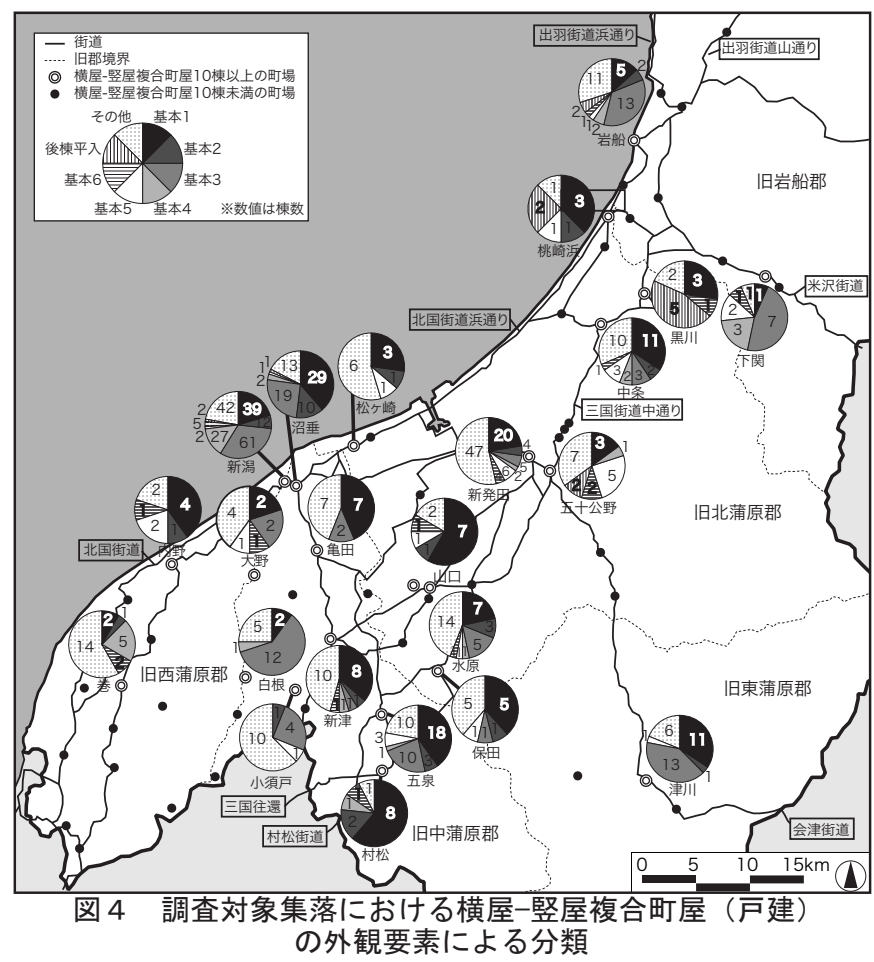

表 3 横屋新潟町の町並みが描かれた絵図一覧

\begin{tabular}{|c|c|c|c|c|c|}
\hline \multirow{2}{*}{ 名称 } & \multirow{2}{*}{ 年代 } & \multirow{2}{*}{ 場所 } & \multicolumn{2}{|c|}{ 棟向き } & \multirow{2}{*}{ 分析対象 } \\
\hline & & & 前棟横屋 & 堅屋 & \\
\hline 新潟町之図屏風 & 江戸期 & 不明 & 複数 (1) & 不明 & - \\
\hline \multirow{2}{*}{ 北国一覧写 出羽越後 } & \multirow{2}{*}{1831} & 本町通 & $3(1)$ & 複数 & \multirow{2}{*}{0} \\
\hline & & 横七番町付近 & 複数 $(0)$ & 1 & \\
\hline 新潟真景 & 1849 & 新潟町全域 & $2(0)$ & 複数 & 0 \\
\hline 新潟湊之真景 & 1859 & 横七番町付近 & 複数 $(0)$ & 不明 & - \\
\hline 新潟真景 & 1865 & 横七番町付近 & $6(2)$ & 複数 & 0 \\
\hline 新斥税関之圖 & 1869 & 新潟町全域 & $10(5)$ & 複数 & 0 \\
\hline 新潟県下 越後摘誌 & 1877 & 新潟税関後方 & 不明 & 不明 & - \\
\hline 新潟港日和山真景 & 1881 & 日和山周辺 & 不明 & 不明 & - \\
\hline 越后新潟真景招魂場 & 不明 & 不明 & 不明 & 不明 & - \\
\hline
\end{tabular}
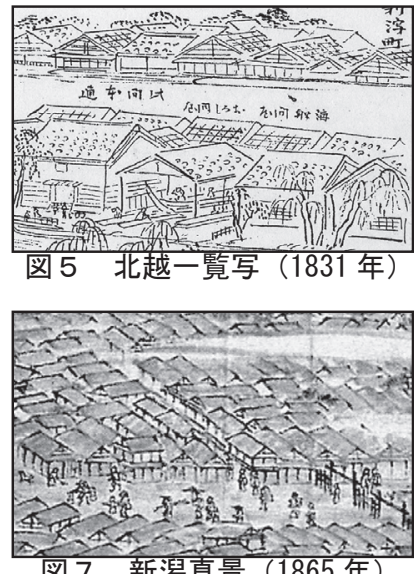

図 7 新渴真景 $(1865$ 年)

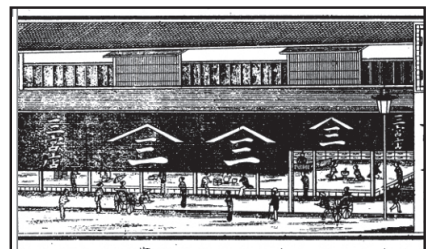

図 9 北越商工便覧 前棟横屋

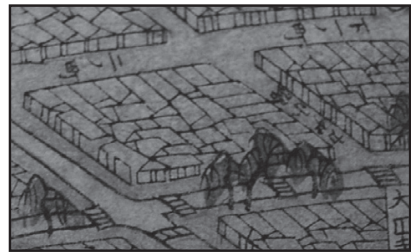

図 6 新埧真景 $(1849$ 年)
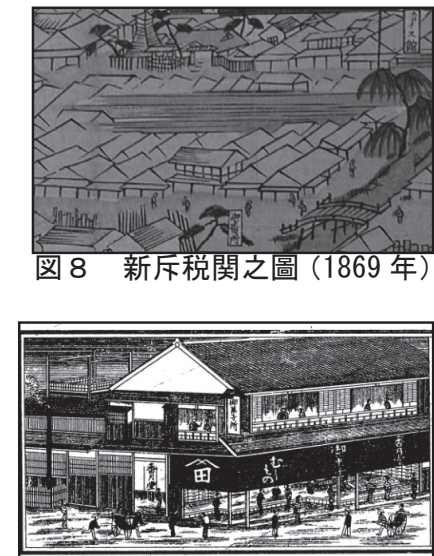

(左)、横屋-竪屋複合町屋（左） 
い者は住んではならないと厳しい内容である。その後、1901 年に 県は耐火構造を義務付ける屋上制限規則を定め、1908 年 3 月の大 火後に改正されているが、いずれについても景観に配慮した条文は ない。また、1908 年 9 月の大火後に新潟新聞で新築する者に建築 制限を知らせる記事 ${ }^{31)}$ が掲載され、そのなかに「街路に面したる 屋根は横屋根に作る事」とある (図 12)。1908 年新潟繁昌記 24 号 32) の「横屋根の新潟」という挿絵（図 13）では前棟横屋の町並み であることから、横屋根は横屋を指していると考えられる。この規 制の実効は不明である ${ }^{33)}$ が、横屋-竪屋複合町屋の普及に少なから ず影響していると考えられる。

\section{5-6. 1908 年（明治 41 年）大火後の新潟町の変化}

新潟繁昌記は、明治後期の花柳界の様子を人物や出来事を中心に 記され、そのなかで大火後の町の変化についても記述されている。 1908 年 3 月の大火に伴い第 3 号で「去三月の大火に全焼した古町 五之町、昨今は余程家屋も建築されて、元の国粹座邊を除く他は町 形をなして来た。別けて石黒商店の上手の方は皆んな東京風の八イ カラ作り、一寸見た丈けでも気が薩張する。愈々全然出来上つたな らば奇麗な町となるであろう。」とある。た、9月の大火に伴い
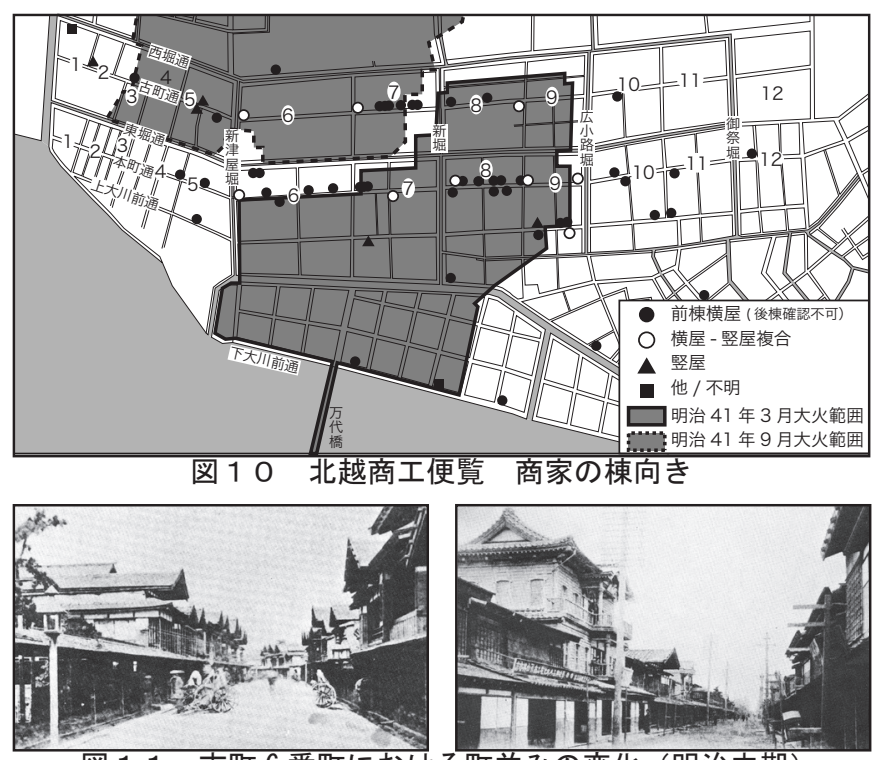

図 11 古町 6 番町における町並みの変化（明治中期）

第 13 号で「今までの古町通六番町は、雪国の模範町だったが、今 度は、此の雪国の模範町は廃めて、全て東京式に庇なしとなり、各 商店又た随分思ひ切て、建築風をハイカラにしたから全部工を終つ た暁は、新潟市の銀座街となる事と思はれる。」とある。以上から、 大火を契機として雁木がなくなり、洋風建築の様式を取り入れたと 思われる。

また、第 15 号で「今回二回の大火に、古町通三番町から八番町 までは凡て庇無し横瓦屋根の作りと変じて」とあり、ここでの横瓦 屋根とは瓦葺きの横屋であると考えられるので、石置き板葺きの竪 屋から瓦莫きの横屋へと町並みが変化したと推測できる。また、第 54 号で大火後に古町 6 番町のほとんどの建物が新潟式から東京式 に変わったことが記載されている（図 14）。前述のとおり古町 6 番 町では明治中期に竪屋の町並みから前棟横屋の町並みに変化してい

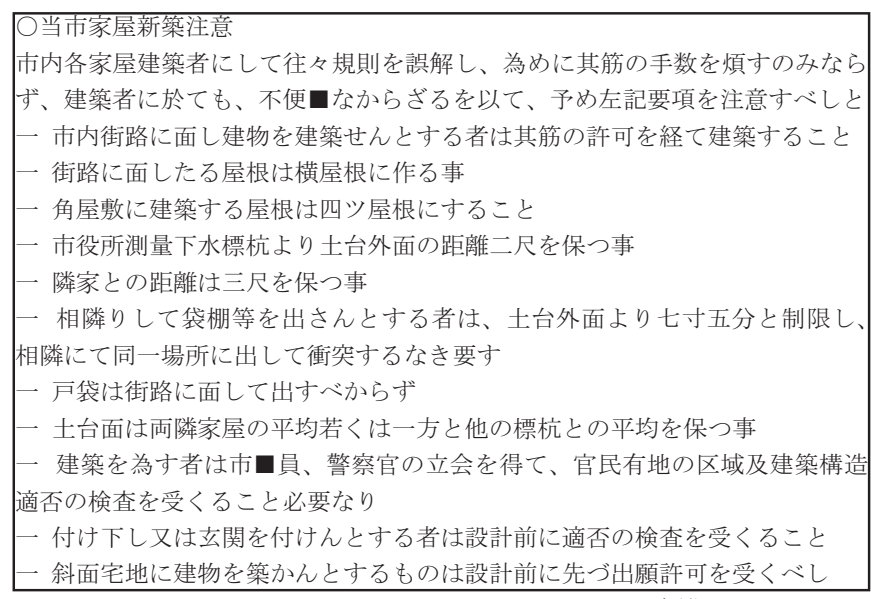
図 12 当市家屋新築に関する記事注 ${ }^{14)}$

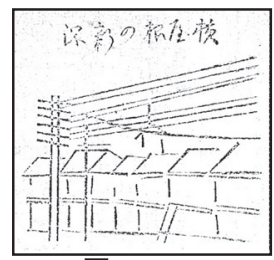

図 13

横屋根の新潟

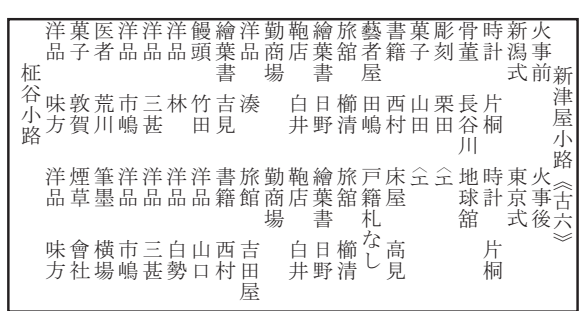

図 14 大火前後の新潟式から 東京式への変化（古町通 6)

表 4 町並み古写真における棟向きの変化

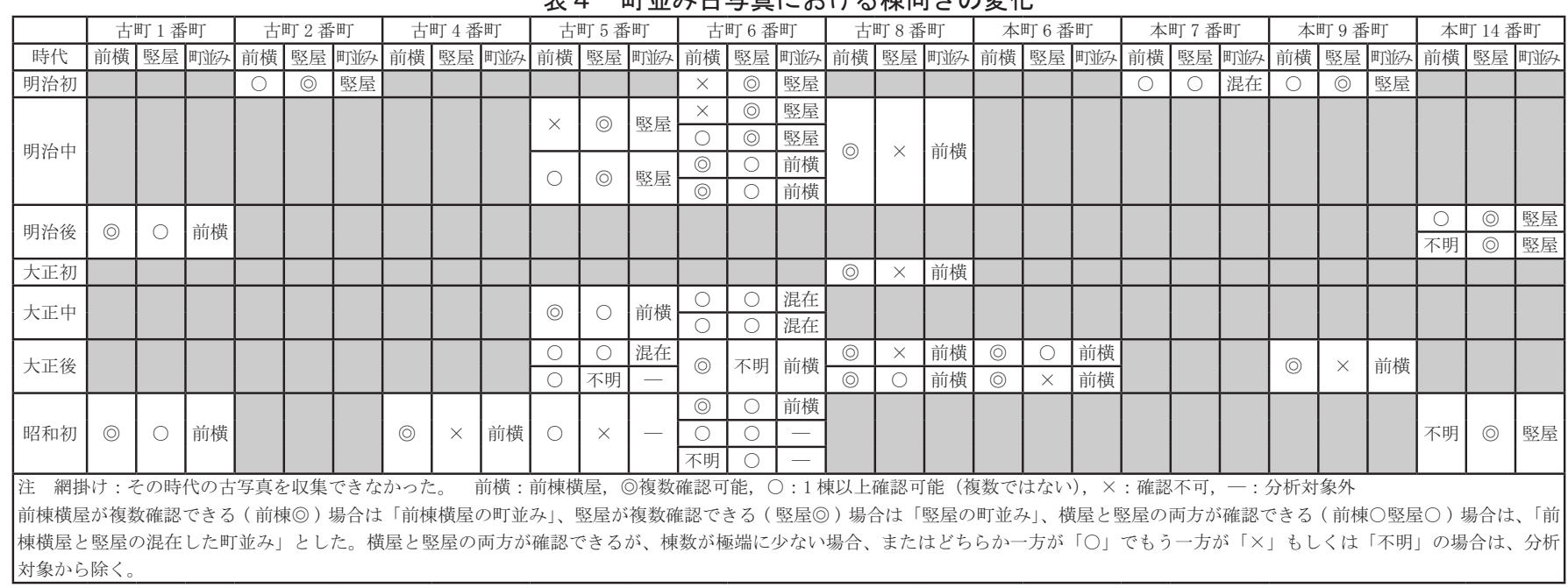


ることから、東京式には横屋であることは含まれないと考えられる。

以上から、東京式とは庇なしであると推測され、1908 年の大火 を契機として町並みは竪屋の庇ありから前棟横屋庇なしへと一変し たと考えられる。

\section{6. 結論}

（1）横屋-竪屋複合町屋は下越地方の岩船郡北部及び西蒲原郡南部 にはほとんど見られず、旧中蒲原郡から旧北蒲原郡西部にかけて多 く分布している傾向がある。横屋が大半を占める村上・瀬波におい ては横屋-堅屋複合町屋は確認できず、横屋-竪屋複合町屋が確認さ れたすべての集落において堅屋が確認できたことから、横屋-堅屋 複合町屋は竪屋から派生した可能性を指摘できる。

(2) 外観要素による分類でもっとも多いタイプは外形が I 字型、前 棟 2 階建て、後棟平屋、玄関面が前棟平入、後棟の奥行が長のもの で 198 棟見られた。

（3）旧新潟町は江戸時代後期から明治初期にかけて竪屋の町並みで あったと推察され、明治中期から前棟横屋（横屋一堅屋複合町屋） を確認できる。また、1908 年（明治 41 年）の市内建築要項が横屋 一竪屋複合町屋の普及に影響を及ぼした可能性を指摘できる。

（4）本研究は都市計画的視点からの研究であり、例えば横屋-豎屋 複合町屋の成立過程について、堅屋の一部を増築し横屋-竪屋複合 町屋としたのか、竪屋全部を改築したのか不明確であり、構造や間 取りなど建築史、建築計画分野からの詳細な研究が今後期待される。 また都市計画的視点からも他地域との比較が必要である。

\section{謝辞}

本稿を作成するにあたり、調查及び資料整理に協力をいただいた 北元裕子にお礼申し上げます。

\section{注}

注 1）参考文献 3）によると、妻入とは大棟と平行な方向に入口のあること、す なわち建物の妻側に入り口がある場合をいい、平入とは大棟と直角方向に入 ロがあること、すなわち建物の平側に入口がある場合をいう。

注 2) 参考文献 3）によると、竪屋とは山形県庄内、岐阜県西部、北陸地方にお いて妻入民家のこと。間口が狭くて細長いからではなく、棟筋が道と直角に なっているからであろう、とある。また、横屋とは岐阜県西部、北陸地方の 民家において平入のこと、とある。

注 3）全国的には類似形態として、新潟県関川村下関の撞木造り ${ }^{11}$ 、福井県三 国のかぐら建て ${ }^{12)}$ 、関東から南東北一円にかけての店棟造り ${ }^{1)}$ 等がある。

注 4）新潟市中央区に位置する、明治初期の新潟町のことである。

注 5）上空から俯瞰した建造物の形状を外形と呼ぶこととする。長方形の場合 を I 字型、曲屋などを L 字型、撞木造りなどを T字型とする。

注 6）主要街道とは参考文献 15）に掲載された街道である。

注 7) 本研究では、概致 1945 年以前に建てられた建造物と定義する。概衫とす る理由は、目視で簡易的に調查するため正確な建築年を把握することが困難 で、また様式で判断するため具体的な年代で判断することができないためで ある。

注 8) 30 棟以上とする理由は、ある程度の棟数がないと各集落の棟向きの傾向 がわからないためである。この方法の場合、旧岩船郡北部では対象集落が少 なくなるため、旧岩船郡のみは 10 棟以上とした。

注 9) 参考文献 16〜22)の他、個人所有の資料である「新潟港日和山真景 (1881)」 及び「越后新潟真景・招魂場（年代不詳）」を調查した。

注 10) 前棟と後棟それぞれの階数を調査した。図 3 では、(前棟階数)-(後棟階数) で階数を示した。

注 11）玄関の位置が前棟にあるものと後棟にあるものの分類と、棟と玄関面の 位置を調查した。

注 12)「後棟奥行」は敷地条件による影響も考えられるが、本研究での外観はファ
サードのデザインだけでなく、建物全体のボリュームによる形も含めたもの と捉えていることから、類型項目としてに含めた。

注 13）本研究では外観類型のみで分類したが、今後建築年代も含めた詳細な分 類が必要である。なお、新潟においては旧小澤家住宅が明治前期に建築され たことと、現存する「横屋-竪屋複合町屋」のいくつかについてヒアリング 調査を行った結果、昭和初期に建築されたものが多かった。

注 14）絵図収集に際して新潟市歴史博物館伊東祐之氏にアドバイスを頂いた。

注 15）曰は判読できなかった文字である。

\section{参考文献}

1) 大場修：近世近代町家建築史論, 中央公論美術出版, 2004. 12

2) 宮本雅明 : 都市空間の近世史研究, 中央公論美術出版, 2005.2

3) 彰国社 : 建築大辞典, 彰国社, 1993.6

4）大庭裕雅，岡崎篤行：鉱山町相川における歴史的建造物の残存状況および外 観特性, 日本建築学会技術報告集 No. 331 pp693-696, 2010.6

5）鈴木哲, 山崎完一, 岡章, 佐藤正道 : 新潟の町家の平入り・妻入りに関する 調查研究, 日本建築学会北陸支部研究講演梗概集 F, pp249-252, 1985.6

6) 佐藤憲明・岡崎篤行 : 新潟県岩船郡における歴史的建造物群の残存状況と外 観特性一下越地方の街道沿いを対象として一, その 1 , 日本建築学会計画系 論文集 No. 610 , pp. 141-146, 2006. 12

7）五十嵐浩：新潟県における歴史的建造物群の残存状況とその建築特性一北蒲 原郡地域の街道沿いの集落を対象として一, 新潟大学大学院自然科学研究科 修士論文, 2005.2

8) 加藤健二・岡崎篤行 : 新潟県下越地方における歴史的建造物群の残存状況と 建築特性一中蒲原・東蒲原両郡地域を対象として一, 日本建築学会北陸支部 研究報告集 第 49 号, pp. 449-452, 2006.7

9）渡辺篤史・岡崎篤行 : 新潟県下越地方における歴史的建造物群の残存状況と 建築特性一新潟市及び西蒲原郡を対象として一, 日本建築学会北陸支部研究 報告集第 50 号, pp. 359-362, 2007.7

10）新潟市建築設計協働組合：新潟市文化財旧小澤家住宅整備工事報告書, 新 潟市, 2011

11）財団法人観光資源保護財団 : 鐘木造りの町並と米沢街道一新潟県関川村の村 づくりー, 日本ナショナルトラスト, 1988

12）玉井哲雄 : 近世地方都市における町並の形成一越前三国湊の町家と都市構 造-, 建築史学第 3 号, 1984.9

13）小林勉, 西村伸也, 阿部元 : 沼垂（ぬったり）町・新潟町のせがい造り を持った町家の室空間構成と使われ方の研究-阿賀野川流域の他の町家と のせがい造り形状の比較-, 日本建築学会計画系論文集 No. 551 pp. 115122, 2002.1

14）檜垣友映, 大場修 : 新潟古町の花街建築の建築的特性, 日本建築学会大会 学術講演梗概集, 建築歴史・意匠, pp289-290, 2013.8

15）小村式：図説 新潟県の街道, 郷土出版社, 1994

16）芳明：新潟町之図屏風, 新潟市歴史博物館所蔵, 年代不詳

17）長谷川雪旦：北国一覧写, 新潟県立図書館所蔵, 1831

18) 翠柳斎 : 新潟真景, 紫錦堂蔵版, 新潟大学附属図書館所蔵, 1849

19) 井上文昌：新潟湊之真景, 新潟市歴史博物館所蔵, 1859

20) 行田魁庵 : 新潟真景, 北方文化博物館所蔵, 1865

21）勝川九斎：新斥税関之圖, 新潟県立図書館所蔵, 1869

22) 鈴田平造 : 新潟県下 越後摘誌, 新潟大学附属図書館所蔵, 1877

23）川崎源太郎：北越商工便覧, 龍泉堂, 1889

24）大庭裕雅：新潟県中越地方北部における歴史的建造物群の残存状況と外観 特性一町屋を中心とした町並みに着目して一, 新潟大学大学院自然科学研究 科修士論文, 2011.2

25）小山信次郎：新潟市商業家明細全図，新潟県立図書館所蔵, 1896

26）尾崎紅葉 : 煙霞療養, 春陽堂, 1904

27）初田亨 : 繁華街にみる都市の近代-東京, 中央公論美術出版, 2001

28）沢村洋編：写真集・新潟の街＼cjkstart歴史散歩，新潟日報事業社, 1980

29）新潟日報事業社出版部編：写真集 ふるさとの 100 年〈新潟〉, 新潟日報 事業社, 1980

30）新潟日報事業社出版部：新潟県の 100 年ふるさとの 100 年総集編 $1 \sim 5$, 新潟日報事業社, 1985

31）新潟新聞：当市家屋新築注意, 1908. 10.27

32) 岡田有邦: 新潟繁昌記, 精華堂, 1886

33）新潟市史編纂古代史部会編：新潟市史 通史篇 3, 新潟市役所, 1996 


\section{DISTRIBUTION AND DESIGN CHARACTER OF “YOKOYA-TATEYA MIX TO MACHIYA” IN KAETSU REGION, NIIGATA PREFECTURE}

\section{Atsushi WATANABE* and Atsuyuki OKAZAKI**}

* Grad. Stud., Grad. Sch. of Science and Technology, Niigata Univ., M.Eng.

** Prof., Dept. of Civil Eng. and Arch., Faculty of Eng., Niigata Univ., Dr.Eng.

Kaetsu region is the northern part of Niigata prefecture. Major towns in this area are three castle towns(johkamachi);Murakami, Shibata, Muramatsu, and four port towns(minato-machi); Senami,Iwafune,Nuttari,Niigata. Additionally, there are many small towns in countryside(zaigoh-cho) along major roads and rivers. Many historical buildings remain in these towns.

One type of historical building is Machiya, which is traditional merchants' commercial and residential building. External form of Machiya is classified into two types; Tateya whose ridge of the roof is vertical to the attached street and Yokoya whose ridge is horizontal. Besides, there is Machiya that is mixture of Tateya and Yokoya in Kaetsu area. The front part of this Machiya is Yokoya, and the back part, which is predominant, is Tateya.

The pupose of this paper is to clarify the number and the percentage of remaining Yokoya-Tateya mixed Machiya in Kaetsu area, and to understand design character of this building. Major results are as fillows:

1) No Yokoya-Tateya mixed Machiya exist in nothern and southern Kaetsu region. On the other hand, there are many Yokoya-Tateya mixed Machiya in Naka-kanbara district and western Kita-kanbara district. It may be inferred that Yokoya-Tateya mixed Machiya was formed from Tateya. One of the reasons is becouse no Yokoya-Tateya mixed Machiya can be found in towns which are consisted purely of Yokoya.

2) Several types of facade design are extracted from 740 Yokoya-Tateya mixed Machiya.

3) As seen in old paintings and photographs, most Machiya in Niigata were Tateya in the late Edo and early Meiji period. The townscape changed in the mid meiji period, and many Yokoya-tateya mixed Machiya emerged. This might be a result of building guidelines proclaimed after the two great fires. 